\title{
Pengaruh Model Pembelajaran dan Motivasi Berprestasi Terhadap Hasil Belajar Sejarah di SMA Negeri 4 Karawang
}

Oleh: Ikina Sabilillah N.,Tuti Nuriah, Umasih

SMA Negeri 1 Karawang

ikinahistoria@gmail.com

\begin{abstract}
The aim of this research is to find the influence of a model of learning and achievement motivation to History Learning Outcomes in SMA Negeri 4 Karawang.This study is a kind of research quantitative with using the experiment design treatment by level $2 x 2$. This research is quantitative which using experiment design treatment method by level $2 x 2$.The population in this research are all the students in elevent grade,Sampel of research are XI IIS 2 and XI IIS 3 people a mount 60. The Instruments that used to the study the history learning outcomes is multiple choice and the instrument that used to know the result of achievement motivation is quisioner. The results of research refer to: (1) History learning outcomes that was giving STAD Learning Model is higher than was giving Direct Learning, (2) There is the influenanceimteraction between learning model and achievement motivation, (3) History learning outcomes that has achievement motivation and STAD Learning model is higher than was giving Direct learning model. (4) History learning outcome that has achievement motivation low and was giving STAD Learning model than was giving Direct Learning model.
\end{abstract}

Keywords: history learning outcomes, instructional model, achievement motivation.

Abstrak: Penelitian ini bertujuan untuk mendapatkan data empiris mengenai pengaruh model pembelajaran dan motivasi berprestasi terhadap hasil belajar sejarah siswa di SMA 4 Karawang.Penelitian kuantitatif ini menggunakan metode eksperimen desain treatment by level 2x2. Populasi pada penelitian ini yaitu seluruh siswa kelas XI, untuk Sampel terdiri dari dua kelas yaitu kelas XI IIS 2dan XI IIS 3 berjumlah 60 siswa. Instrumen yang digunakan untuk hasil belajar sejarah yakni dengan tes pilihan ganda dan untuk motivasi berprestasi dengan menggunakan kuesioner. Hasil Penelitian ini menunjukkan bahwa: (1) hasil belajar sejarah siswa yang mengikuti model pembelajaran STAD lebih tinggi daripada siswa yang menggunakan model pembelajaran langsung, (2) Terdapat pengaruh antara model pembelajaran dan motivasi berprestasi, (3) hasil belajar sejarah antara siswa yang memiliki motivasi berprestasi tinggi dan menggunakan model pembelajaran STAD dengan siswa yang menggunakan model pembelajaran langsung, (4) hasil belajar sejarah antara siswa yang memiliki motivasi berprestasi rendah dan menggunakan model pembelajaran STAD dengan siswa yang menggunakan model pembelajaran langsung.

Kata Kunci: hasil belajar sejarah, model pembelajaran, motivasi berprestasi,

\section{PENDAHULUAN}

Hasil observasi awal di SMA Negeri 4 Karawang, dalam pembelajaran sejarah guru menggunakan model pembelajaran langsung yang dibantu oleh media Power Point. Model pembelajaran langsung merupakan model yang sangat baik dalam menyampaikan informasi kepada siswa namun lebih 
cenderung pada pendekatan Teacher Center, sebagian siswa yang benar-benar fokus memperhatikan karena antar kelas hanya dibatasi oleh rolling door sehingga menyebabkan keadaan kelas menjadi berisik, Siswa kurang responsif saat guru memberikan rangsangan, dan adanya dominasi beberapa siswa didalam kelas.

Belajar sejarah seharusnya menjadi hal yang menyenangkan dimana pembelajaran sejarah seharusnya lebih kearah Student Center, Siswa membutuhan ruang belajar yang kondusif, Guru harus mampu menumbuhkan keaktifan siswa, dan meratanya kemampuan dan kesempatan siswa untuk berpartisipasi aktif di kelas.

Motivasi berprestasi dapat timbul karena faktor intrinstik yang berasal dari dalam diri sendiri yang disebabkan oleh dorongan atau keinginan untuk belajar dan meraih harapan. Adapula faktor ekstrinsik yang mempengaruhi dalam belajar yang berasal dari adanya penghargaan, lingkungan belajar yang menyenangkan, dan kegiatan belajar yang menarik. Motivasi berprestasi intrinstik berasal dari dalam diri siswa, berupa keinginan untuk belajar dengan giat untuk merealisasikan hasil belajar sejarah yang tinggi. Sedangkan motivasi berprestasi ekstrinsik berasal dari luar diri siswa seperti dari guru yang memiliki peranan penting dalam menumbuhkan motivasi berprestasi siswa melalui berbagai aktivitas belajar yang didasarkan pada pengalaman dan kemampuan guru kepada siswa secara individual. Selain guru, orangtua juga sangat berperan aktif dalam menumbuhkan keinginan untuk belajar dan berprestasi siswa dirumahnya. Dapat dikatakan motivasi berpestasi merupakan dorongan yang berasal dari dalam dan luar siswa yang sedang belajar untuk mengadakan perubahan pada tingkah laku pada umumnya dan keinginan untuk belajar lebih semangat guna mencapai hasil belajar yang tinggi.

Alasan pemilihan judul berdasarkan permasalahan yang dikemukakan di atas maka penelitian ini dilakukan untuk pengoptimalkan motivasi berprestasi yang nantinya dapat berpengaruh terhadap hasil belajar siswa setelah proses pembelajaran berlangsung. Salah satu model pembelajaran yang dapat diigunakan dapat mengoptimalkan kecerdasan emosional yaitu model pembelajaran cooperative learning tipe STAD yang telah dikembangkan dan diuji coba oleh Robert Slavin. Penelitian ini dikhususkan untuk mengetahui pengaruh model pembelajaran dan motivasi berprestasi terhadap hasil siswa pada mata pelajaran sejarah SMA Negeri 4 Karawang.

Anderson dan Krathwohl (2015:95-96) menyatakan hasil belajar didapat dari tiga macam skenario, yaitu: (1) Tidak ada aktivitas belajar, (2) belajar menghafal, (3) belajar yang bermakna.

STAD (Student Team Achievement Division) menurut Robert E. Slavin (2005:5) dimana guru yang mengacu kepada belajar kelompok siswa dan menyajikan informasi akademik baru kepada siswa. STAD terdiri dari lima 
komponen utama, yaitu presentasi kelas, tim/kelompok, kuis, skor perkembangan individu, dan rekognisi tim.

Menurut Joyce, Weil, dan Calhoun (2009:427-429) pembelajaran langsung memainkan peran yang terbatas namun penting dalam program pendidikan yang komprehensif. Model pembelajaran langsung terdiri dari lima tahap aktivitas; yakni orientasi, presentasi, praktik yang terstruktur, praktik dibawah bimbingan guru dan praktik mandiri.

Menurut Turner dan Johnson (2011:111-112) motivasi berprestasi atau pencapaian sangat dipengaruhi pengalaman keluarga tetapi setelah anak-anak berada disekolah selama beberapa tahun keberhasilan dan motivasi saling mengakibatkan satu sama lain.

Penelitian relevan yang dilaksanakan oleh Ahmad Muhlisin yang berjudul "Pengembangan perangkat pembelajaran IPA terpadu berbasis Contextual Teaching and Learning dengan model pembelajaran kooperatif tipe Student Teams Achievement Division (STAD) tema polusi udara". Disimpulkan sebagai berikut: Model pembelajaran kooperatif tipe STAD tema polusi udara mencapai criteria praktis dengan keberhasilan indikator respon positif ditunjukkan sebesar 87,1\% siswa member respon positif, dan kesan positif yang ditunjukkan oleh guru. Penerapan perangkat pembelajaran IPA terpadu dengan model pembelajaran kooperatif tipe STAD tema polusi udara dapat meningkatkan hasil belajar (kognitif) siswa.

\section{METODE}

Penelitian ini menggunakan metode eksperimen dengan desain treatment by level $2 \times 2$. Variabel dalam penelitian ini terdiri dari dua variabel bebas yakni model pembelajaran STAD dan motivasi berprestasi. Variabel terikat penelitian ini adalah minat belajar sejarah siswa. Penelitian ini merupakan jenis penelitian eksperimen dengan menggunakan satu kelas kontrol dengan model pembelajaran STAD dan satu kelas eksperimen dengan model pembelajaran langsung. Jumlah populasi target dalam penelitian ini adalah seluruh siswa SMA Negeri 4 Karawang yang berjumlah 864 siswa, sedangkan populasi terjangkau dalam penelitian ini adalah seluruh siswa SMA Negeri 4 Karawang kelas XI IPS sebanyak 60 orang siswa. Pemilihan sampel penelitian ini diambil dengan cara Simple Random Sampling, jumlah siswa yang menjadi subjek penilaian sebanyak 60 siswa yang terdiri dari dua kelas, yaitu kelas eksperimen sebanyak 30 siswa yang diberi model pembelajaran STAD dan kelas kontrol sebanyak 30 siswa yang diberikan model pembelajaran langsung.

Setiap kelas ditetapkan $27 \%$ dari rangking teratas di golongkan sebagai golongan siswa yang memiliki motivasi berprestasi tinggi dan $27 \%$ rangking terbawah digolongkan sebagai golongan siswa yang memiliki motivasi 
berprestasi rendah. Hasil yang diperoleh sebanyak 9 siswa dari golongan motivasi berprestasi tinggi dan motivasi berprestasi rendah. Ujicoba dilakukan untuk memvalidasi instrumen yang akan digunakan untuk mengetahui suatu tes melakukan fungsi ukurnya sehingga hasil ukur sesuai dengan hal yang akan diukur. Uji validitas butir dilakukan dengan Point Biserial Correlation $\left(\mathrm{r}_{\mathrm{pbis}}\right)$. Perhitungan reliabilitas instrumen dapat dilakukan dengan teknik belah dua dari Spearman Brown (sifil half), KR20, yaitu tes yang digunakan untuk menjawab benar salah (dikotomi) tentang materi sejarah. Dalam penerapannya, skor tes yang diberikan adalah 1 bagi responden yang menjawab benar dan skor 0 bagi responden yang menjawab salah.

Data dalam penelitian ini meliputi data hasil belajar sejarah siswa kelas XI IPS yang diambil dengan memakai instrumen tes hasil belajar dan data motivasi beprestasi siswa yang diambil dengan menggunakan instrumen non tes dengan bentuk skala likert.

Teknik analisis data yang dipergunakan dalam penelitian ini adalah teknik Analisis Varians (ANAVA) dua jalur. Teknik ini dipilih karena peneliti ingin mengetahui perbedaan hasil belajar siswa yang dihasilkan melalui model pembelajaran STAD dan langsung. Analisis deskriptif dengan penyajian tabel distribusi, histogram, rata-rata dan simpangan baku. Uji normalitas dalam penelitian ini dengan menggunakan rumus Uji Liliefors, sedangkan uji homogenitas atau uji kesamaan rata-rata bertujuan guna mengetahui apakah data yang diperoleh memiliki varians yang sama atau homogen.

Analisis dengan teknik ANAVA, diharapkan dapat menunjukan signifikan perbedaan pemahaman sejarah yang dihasilkan melalui model pembelajaran STAD dan langsung langsung antara siswa yang memiliki motivasi berprestasi tinggi dan rendah. Akhir analisis, jika hasil menunjukan adanya perbedaan dan interaksi signifikan antara variabel-variabel analisa perlu dilanjutkan untuk menguji kelompok mana yang lebih tinggi dengan menggunakan uji Tuckey.

\section{HASIL}

Pengujian hipotesis dilakukan setelah persyaratan untuk pengujian analisis dapat terpenuhi yakni dengan cara uji normalitas dan homogenitas. Pengujian hipotesis ini dilakukan guna menguji efek utama dan efek interaksi terhadap hasil belajar dengan mengikuti analisis varians dua jalur ANAVA $2 \mathrm{x}$ 2. Efek utama dalam penelitian adalah mengenai pengaruh penggunaan model pembelajaran (STAD dan Langsung) dan Motivasi Berprestasi terhada hasil belajar sejarah siswa SMA Negeri 4 Karawang, sedangkan efek interaksinya mengenai pengaruh interaksi antara penggunaan model pembelajaran yang diberikan pada siswa yang memiliki motivasi berprestasi yang rendah. Taraf 
signifikansinya selanjutnya dilakukan dengan cara uji lanjutan yaitu dengan mengikuti Uji Tuckey.

\section{Rangkuman Hasil Perhitungan Analisis Varians (Anava) Dua Jalur}

\begin{tabular}{|l|l|l|l|ll|l|l|}
\hline Sumber Variansi & \multirow{2}{*}{ Db } & \multirow{2}{*}{ JK } & \multirow{2}{*}{ RJK } & \multirow{2}{*}{ Fitung } & \multicolumn{3}{|l|}{ F $_{\text {tabel }}$} \\
\cline { 7 - 9 } & & & & & 0.05 & 0.01 \\
\hline Antar Kolom & 1 & 98.00 & 98.00 & 13.806 & $*$ & 4.20 & 7.64 \\
\hline Antar Baris & 1 & 3.13 & 3.13 & 0.440 & 4.20 & 7.64 \\
\hline Interaksi & 1 & 450.00 & 450.00 & 63.396 & $* *$ & 4.20 & 7.64 \\
\hline Dalam & 28 & 198.75 & 7.10 & & & & \\
\hline Total Direduksi & 31 & 749.88 & & & & & \\
\hline
\end{tabular}

Berdasarkan perhitungan ANAVA dua jalur diperoleh Fhitung untuk model pembelajaran sebesar 13.806 sedangkan $\mathrm{F}_{\text {tabel }}=3,00$ pada taraf nyata signifikasi $\alpha=0,05$ karena nilai $\mathrm{F}_{\text {hitung }}>\mathrm{F}_{\text {tabel }}$ maka $\left(\mathrm{H}_{\mathrm{o}}\right)$ ditolak dan $\mathrm{H}_{1}$ yang diterima artinya bahwa terdapat perbedaan hasil belajar sejarah antara siswa yang mengikuti model pembelajaran STAD dan langsung.

Hasil Fhitung menunjukkan bahwa terdapat pengaruh hasil belajar sejarah antara siswa yang menggunakan model pembelajaran STAD dengan siswa yang menggunakan model pembelajaran langsung dapat dilihat berdasarkan nilai rata-rata skor model pembelajaran STAD (A1) 27.81, sedangkan nilai ratarata skor model pembelajaran langsung yakni (A2) 24,31, sehingga dapat disimpulkan hasil belajar sejarah siswa yang menggunakan model pembelajaran STAD lebih tinggi dari siswa yang menggunakan model pembelajaran langsung.

Hipotesis kedua terdapat adanya pengaruh interaksi antara penggunaan model pembelajaran dan motivasi berprestasi terhadap hasil belajar sejarah siswa. Berdasarkan hasil perhitungan ANAVA dapat dilihat bahwa Fhitung untuk faktor interaksi yakni 63,396 lebih besar dari $F_{\text {tabel }}$ yakni 4,20 pada taraf nyata signifikasi $\alpha=0,05$. Karena Fhitung $>\mathrm{F}_{\text {tabel }}$ maka $\mathrm{H}_{0}$ ditolak dan $\mathrm{H}_{1}$ diterima. Nilai rata-rata tiap sel diperoleh skor pada kelompok $\mathrm{A}_{1} \mathrm{~B}_{1}$ sebesar 31.88, $\mathrm{A}_{1} \mathrm{~B}_{2} 20.88$, $\mathrm{A}_{2} \mathrm{~B}_{1}$ 23.75, dan $\mathrm{A}_{2} \mathrm{~B}_{2}$ 27.75. Rangkuman hasil uji hipotesis pengaruh antara penggunaan model pembelajaran STAD dan model pembelajaran langsung menunjukan bahwa Fhitung lebih besar daripada $F_{t a b e l}$ yang artinya jika terdapat pengaruh interaksi yang signifikan antara penggunaan model pembelajaran dan motivasi berprestasi siswa terhadap hasil belajar sejarah.

Hipotesis Ketiga Hasil belajar sejarah antara siswa yang memiliki motivasi berprestasi tinggi dengan menggunakan model pembelajaran STAD lebih tinggi dari siswa yang menggunakan model pembelajaran langsung, Nilai rerata hasil belajar sejarah siswa dengan motivasi berprestasi tinggi yang mengikuti model pembelajaran STAD $\left(\mathrm{A}_{1} \mathrm{~B}_{1}\right)$ adalah 31,88 sedangkan nilai 
rerata hasil belajar dengan berprestasi tinggi yang mengikuti model pembelajaran langsung $\mathrm{A}_{2} \mathrm{~B}_{1}$ adalah 20,88 yang kedua nilai ini kemudian dibandingkan dengan mengikuti Uji Tuckey seperti yang dijelaskan sebagai berikut:

Hasil tersebut menunjukan bahwa Qhitung yakni 11,68 > Qtabel yakni 4,04 pada taraf signifikansinya $\alpha=0,05$, dengan demikian maka dapat disimpulkan bahwa $\mathrm{H}_{0}$ ditolak $\mathrm{H}_{1}$ diterima yang dapat diartikan jika para siswa yang memiliki motivasi berprestasi tinggi terdapat perbedaan hasil belajar dengan siswa yang mengikuti model pembelajaran langsung. Rangkuman hasil Uji Tuckey dapat dilihat pada tabel yang tertera dibawah ini:

Hipotesis Keempat hasil belajar sejarah antara siswa yang memiliki motivasi berprestasi rendah dengan menggunakan model pembelajaran STAD lebih rendah dari siswa yang menggunakan model pembelajaran langsung. Nilai rerata hasil belajar sejarah siswa dengan motivasi berprestasi yang mengikuti model pembelajaran STAD $\mathrm{A}_{1} \mathrm{~B}_{2}$ adalah 23,75 , sedangkan nilai rerata hasil belajar sejarah siswa dengan motivasi berprestasi rendah yang mengikuti model pembelajaran langsung $\mathrm{A}_{2} \mathrm{~B}_{2}$ adalah 27,75. Kedua nilai kemudian diuji dengan menggunakan Uji Tuckey hasil tersebut menunjukan bah/wa Qhitung yakni 11,68 lebih besar daripada Qtabel yakni 4,04 pada taraf signifkansinya $\alpha=$ 0,05, dengan demikian dapat simpulkan bahwa $\mathrm{H}_{0}$ ditolak dan $\mathrm{H}_{1}$ diterima yang dapat diartikan jika terdapat perbedaan hasil belajar sejarah siswa yang memiliki motivasi berprestasi rendah yang mengikuti model STAD dan siswa yang memiliki motivasi berprestasi rendah yang mengikuti model pembelajaran langsung.

\section{PEMBAHASAN}

Hasil Pengujian pada hipotesis pertama menunjukan hasil belajar sejarah siswa yang mengkuti model pembelajaran STAD lebih tinggi daripada hasil belajar sejarah siswa yang mengikuti model pembelajaran Langsung. Hasil Fhitung menunjukkan bahwa terdapat pengaruh hasil belajar sejarah antara siswa yang menggunakan model pembelajaran STAD dengan siswa yang menggunakan model pembelajaran langsung dapat dilihat berdasarkan nilai rata-rata skor model pembelajaran STAD (A1) 27.81, sedangkan nilai rata-rata skor model pembelajaran langsung yakni (A2) 24,31, sehingga dapat disimpulkan hasil belajar sejarah siswa yang menggunakan model pembelajaran STAD lebih tinggi dari siswa yang menggunakan model pembelajaran langsung.

Hasil Pengujian pada hipotesis kedua terdapat adanya pengaruh interaksi antara penggunaan model pembelajaran dan motivasi berprestasi terhadap hasil belajar sejarah siswa. Berdasarkan hasil perhitungan ANAVA dapat dilihat bahwa Fhitung untuk faktor interaksi yakni 63,396 lebih besar dari 
$\mathrm{F}_{\text {tabel }}$ yakni 4,20 pada taraf nyata signifikasi $\alpha=0,05$. Karena $F_{\text {hitung }}>\mathrm{F}_{\text {tabel }}$ maka $\mathrm{H}_{0}$ ditolak dan $\mathrm{H}_{1}$ diterima. Nilai rata-rata tiap sel diperoleh skor pada kelompok $\mathrm{A}_{1} \mathrm{~B}_{1}$ sebesar 31.88, $\mathrm{A}_{1} \mathrm{~B}_{2}$ 20.88, $\mathrm{A}_{2} \mathrm{~B}_{1}$ 23.75, dan $\mathrm{A}_{2} \mathrm{~B}_{2}$ 27.75.

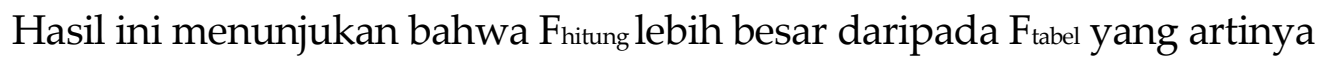
jika terdapat pengaruh interaksi yang signifikan antara penggunaan model pembelajaran dan motivasi berprestasi siswa terhadap hasil belajar sejarah.

Hasil pengujian pada hipotesis ketiga, Hasil belajar sejarah antara siswa yang memiliki motivasi berprestasi tinggi dengan menggunakan model pembelajaran STAD lebih tinggi dari siswa yang menggunakan model pembelajaran langsung pada proses yang terjadi siswa yang memiliki motivasi berprestasi mampu mengikuti model pembelajaran STAD dengan baik.Nilai rerata hasil belajar sejarah siswa dengan motivasi berprestasi tinggi yang mengikuti model pembelajaran STAD $\left(\mathrm{A}_{1} \mathrm{~B}_{1}\right)$ adalah 31,88 sedangkan nilai rerata hasil belajar dengan berprestasi tinggi yang mengikuti model pembelajaran langsung $\mathrm{A}_{2} \mathrm{~B}_{1}$ adalah 20,88 yang kedua nilai ini kemudian dibandingkan dengan mengikuti Uji Tuckey. Hasil tersebut menunjukan bahwa Qhitung yakni 11,68 > Qtabel yakni 4,04 pada taraf signifikansinya $\alpha=0,05$, dengan demikian maka dapat disimpulkan bahwa $\mathrm{H}_{0}$ ditolak $\mathrm{H}_{1}$ diterima yang dapat diartikan jika para siswa yang memiliki motivasi berprestasi tinggi terdapat perbedaan hasil belajar dengan siswa yang mengikuti model pembelajaran langsung.

Hasil Pengujian pada hipotesis keempat, hasil belajar sejarah antara siswa yang memiliki motivasi berprestasi rendah dengan menggunakan model pembelajaran STAD lebih rendah dari siswa yang menggunakan model pembelajaran langsung. Nilai rerata hasil belajar sejarah siswa dengan motivasi berprestasi yang mengikuti model pembelajaran STAD $\mathrm{A}_{1} \mathrm{~B}_{2}$ adalah 23,75, sedangkan nilai rerata hasil belajar sejarah siswa dengan motivasi berprestasi rendah yang mengikuti model pembelajaran langsung $\mathrm{A}_{2} \mathrm{~B}_{2}$ adalah 27,75. Hasil tersebut menunjukan bahwa Qhitung yakni 11,68 lebih besar daripada Qtabel yakni 4,04 pada taraf signifkansinya $\alpha=0,05$, dengan demikian dapat simpulkan bahwa $\mathrm{H}_{0}$ ditolak dan $\mathrm{H}_{1}$ diterima yang dapat diartikan jika terdapat perbedaan hasil belajar sejarah siswa yang memiliki motivasi berprestasi rendah yang mengikuti model STAD dan siswa yang memiliki motivasi berprestasi rendah yang mengikuti model pembelajaran langsung.

\section{PENUTUP}

Hasil penelitian ini menunjukan bahwa: (1) hasil belajar siswa yang mengikuti model pembelajaran STAD lebih tinggi dari hasil belajar siswa yang menggunakan model pembelajaran langsung (2) Terdapat pengaruh anatara model pembelajaran dan motivasi berprestasi siswa terhadap hasil belajar sejarah (3) Hasil belajar sejarah antara siswa yang memiliki motivasi berprestasi 
tinggi dengan menggunakan model pembelajaran STAD lebih tinggi dari siswa yang menggunakan model pembelajaran langsung (4) Hasil belajar sejarah antara siswa yang memiliki motivasi berprestasi rendah dengan menggunakan model pembelajaran STAD lebih rendah dari siswa yang menggunakan model pembelajaran langsung.

\section{DAFTAR PUSTAKA}

[1] Anderson, W. Lorin dan David R. Krathwohl (2015) Kerangka Landasan untuk Pembelajaran, Pengajaran, dan Asesmen: Revisi Taksonomi Pendidikan Bloom,Jakarta: Pustaka Pelajar

[2] Arikunto, Suharsimi (2013) Manajemen Pendidikan, Jakarta: Rineka Cipta

[3] Bruce Joyce, Marsha Weil, Emily Calhoun. (2009) Models of Teaching , Yogyakarta:Pustaka Pelajar

[4] Lorin W. Anderson dan David R. Krathwohl. 2015 Kerangka Landasan untuk Pembelajaran, Pengajaran, dan Asesmen: Revisi Taksonomi Pendidikan Bloom ,Yogyakarta:Pustaka Pelajar

[5] Slavin, Robert E, 2005,Cooperatif Learning: Teori, Riset, dan Praktik, Bandung: Penerbit Nusa Media

[6] Slavin, Robert E, 2011Psikologi Pendidikan: Teori dan Praktik.Jakarta:PT Indeks

[7 Sugiyono, 2006 Metode Penelitian Pendidikan, Pendekatan Kuantitatiff, Kualitatif dan RED, Bandung:Alfabeta, 